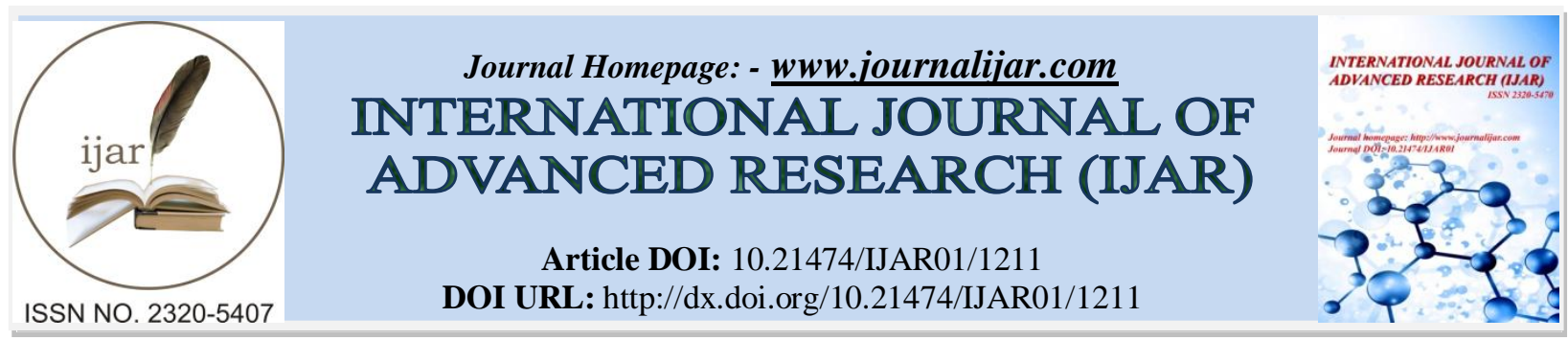

RESEARCH ARTICLE

\title{
GOLD PRICES AND NIFTY - UNRAVELLING OF AN INTRICATELY INTERWOVEN NEXUS.
}

\section{Dr. Shehnaz S.R ${ }^{1}$ and Prof. Suresh Kumar $S^{2}$.}

1. Assistant Professor, PG Department of Commerce, T K M College of Arts and Science (Affiliated to University of Kerala) Kollam, Kerala, India. 691005.

2. Associate Professor and Head, PG Department of Commerce, T K M College of Arts and Science (Affiliated to University of Kerala) Kollam, Kerala, India. 691005.

\section{Manuscript Info}

Manuscript History

Received: 12 June 2016

Final Accepted: 18 July 2016

Published: August 2016

Key words:-

Nifty, Gold Price, Ganger Causality, Johansen Co-integration, Wald Test, VECM, Impulse Response Function.

\begin{abstract}
With the ever changing financial architecture prevalent in the economy and opening up of new vistas of financial engineering highlighting the financial inclusion and education schemes coupled with introduction of new financial instruments, India has been able to widen the net of investments either domestic or foreign direct. The scope of investment by individuals though hovers around safe avenues such as gold, the increasing trend of investment in stock markets cannot be ruled out. However the euphoria and dysphoria associated with up rises and down falls in stock market prices, whether it is consequent to global recessionary factors or domestic political and economic scenario, often pulls or drives away investors to or from the stock markets, especially in the short run. Besides the influence of macroeconomic factors on stock prices, the influence of gold prices on stock prices has spurred the inquisitiveness of researchers all over the world.

This paper presents the intricately interwoven nexus that can be established between gold prices in India and the vibrant National Stock Exchange index Nifty50. Published historical stock index data and historical movements in the gold price per gram in Indian Rupees obtained from official websites of National Stock Exchange (NSE), India and World gold Council are used to build and develop econometric models. The experiments to identify the dynamics and intricacies of nexus between the variables establishes the impact of gold price on stock market index Nifty vis-à-vis their short-run and long-run causal relationship.
\end{abstract}

Copy Right, IJAR, 2016,. All rights reserved.

\section{Introduction:-}

The euphoria and dysphoria associated with up-rises and down-falls in stock market prices have been a repeated phenomenon over years and the researchers' inquisitiveness over the cause effect analysis had never been eradicated. The enquiries into the relationship between various macro economic factors and investment in other vehicles in terms of risk and return had always been in the limelight. With a number of options available, the investor has to choose the desired avenue for investing his hard earned savings, notwithstanding the temptations of a 
quick and higher return that surpasses the risk they are willing to seek or avert. Among other options, investment in gold, one of the most popular precious metals, has traditionally been favoured at least in the Indian sub continent. Though alternatives for diversifying risk exists in the form of exchange traded funds as well as futures contracts and derivatives, investment in physical gold has not lost its dominance among Indian investors. The gold market is also subjected to speculation and volatility as in other markets and the correlation that exist between capital market and commodity market has been the area of interest of study among econometricians and researchers.

Investing money in gold has been considered worth since it can act as a hedge against inflation. Time and again it has been proved that over a period of time, the return on gold investment turns out to be in line with the rate of inflation. Ramalingam (2014) is of the opinion that it is worth investing in gold for a one more very valid reason. He identifies that gold is negatively correlated to equity investments and states that for example in India 2007 onwards, the equity markets started performing poorly whereas the gold has performed well. The favourable gold prices are expected to attract investments away from stock markets at times of high volatility in stock prices and indices. Though China has surpassed India as the largest importer of gold, gold prices in India never showed a continuous declining trend. On the contrary it has witnessed unprecedented highs intermittently.

The Nifty 50, the professionally maintained index of National Stock Exchange, India represents a diversified 50 stocks that accounts for 13 sectors of the economy. It is viewed as the indicator of Indian Capital markets besides Bombay Stock Exchange BSE- Sensex. The use of Nifty 50 as indicator of Indian capital market can be justified from its composition since it represents about $65 \%$ of the free float market capitalization of the stocks listed on NSE as on March 31, 2016. Besides, the total traded value of Nifty 50 index constituents for the last six months ending March 2016 is approximately $46 \%$ of the traded value of all stocks on the NSE. (Source: official website of NSE India available at https://www.nseindia.com/products/content/equities/indices/nifty_50.htm).

Gold prices, by and large, rise when attitudes on the economy and the financial markets are bearish or there is uncertainty over future trends. In the $70^{\mathrm{ee}} \mathrm{s}$, the price of gold soared significantly, while stock markets remained stagnant. However, in the recent past two decades, gold price remained comparatively stagnant, and the stock market gave exceptional returns [Banumathy Karunanithy and Azhagaiah Ramachandran (2014 a)]. Granger (1986) and Johansen and Juselius (1990) proposed to determine the existence of long-term equilibrium among selected variables through co-integration analysis, paving the way for a (by now) preferred approach to examining the economic variables-stock markets relationship. A set of time-series variables are co-integrated if they are integrated of the same order and a linear combination of them is stationary. Such linear combinations would then point to the existence of a long-term relationship between the variables. An advantage of co-integration analysis is that through building of an error-correction model (ECM), the dynamic co-movement among variables and the adjustment process toward long-term equilibrium can be examined [Saluja, Dr. Manminder Singh and Bhatia, Navneet Kaur and Patel, Nishant (2013)]

An attempt is made in this paper to develop an exhaustive econometric time series model that can validate the intricately interwoven cause effect relationship between gold prices in India and close prices of Nifty Index. The rest of the sections of this paper are devoted to literature review and explanation of the problem, design adopted, existing studies, methodology pursued and experimental results before concluding the summary of findings.

\section{Literature Review:-}

A large number of studies have been made in the context of influence of macroeconomic factors as well as commodity prices and industrial production on capital market indices. Ramanthan K V and Meenakshisundaram K S (2016) compared various investment avenues and examined the performance of the return of Gold ETF, physical gold and Nifty indices. They have observed that while nifty and nifty junior were able to produce positive returns, investment in gold whether physical or ETF could not and hence inferred that investment in Gold ETF is not a wise decision. However the period of data used for analysis was very short and covered only a three year period of March 2012 to March 2015 and hence could not substantiate the effect of gold price return and return from nifty indices. Khan Gholam Syedain and Sarker Shah Md. Al-Emran (2014) examined the evidence from India regarding dynamic interactions between commodity market and capital market. Their study based on relatively long period data of 22 years from April 1991 to March 2013 confirms the existence of long run equilibrium relationship between gold and sensex and establishes that there is a bi-directional relationship in the long-run between the two variables. The negative but low correlation between gold and sensex, found by them made them inclined to suggest the favourable property of gold as an investment asset for the Indian emerging market and concludes that at least, gold provides a 
diversification and safe haven benefit to investors in the Indian market.. Though they had been able to use relatively large number of observations, their analysis might have been handicapped by the monthly data which lacks pronunciation both in the case of Sensex as well as gold prices.

Banumathy Karunanithy and Azhagaiah Ramachandran (2014 a) studied Causal Relationship between Stock Price and Gold Price in India using Granger Causality Test Approach and examined the causal link between BSE Sensex (SENSEX) and gold price (GOLD). They relied on time series data (monthly) of BSE Sensex and gold price for the period from January 2004 to December 2013 and found that there exists a causal relationship, which is running from SENSEX to GOLD. However they couldn't find such relationship that exists from GOLD to SENSEX. They conclude that there is a unidirectional relationship that existed between stock price and gold price. Their study was confined to monthly data and limited test of granger causality and Johansen co integration test. Banumathy Karunanithy and Azhagaiah Ramachandran (2014 b) identified Long-Run and Short-Run Causality between Stock Price and Gold Price supported by evidence of VECM Analysis from India. Data pertaining to a period of ten years ranging from 1st April 2004 to 31st March 2014 were analysed to find existence of long-run causality from BSE to GOLD, whereas they found no short-run causality running from the variable. By reversing the dependent and independent variable, they also observed the nonexistence of long-run and short-run causality running from GOLD to BSE.

Saluja, Dr. Manminder Singh Bhatia, Navneet Kaur and Patel, Nishant (2013) studied the effect of Subprime crisis of 2007-08 and macroeconomic problems of subsequent recessionary period in many countries and present scenario of the Indian economy exposed to many macroeconomic problems like current account deficit. They identified the role of FDI to finance the deficit and investigated the relationship between foreign direct investments (FDI) \& the current account (CU) and capital account (CA) in context of Indian economy. They found relationships between variables for the period of 1991 Q1-2012 Q4 and concluded that FDI-CU and FDI-CA are co-integrated in the long run. They observed that the current account balance has a negative relationship to FDI but capital account made a positive impact on FDI after the liberalization of the economy. Narang S.P and Singh Raman Preet (2012) investigated the existence of unidirectional or bidirectional relationship between gold price and Sensex for the period of 10 years (2002-2012) and observes that there is no causality between the gold price and Sensex. They have further found a positive correlation between stock returns and gold price from 2002 to 2007 but admit that due to the global economic crisis between 2008 and 2011 this correlation appeared to be fading. They further established that there is no relation between gold prices and stock returns by using correlation and Johansen's co-integration. They used Granger causality test to substantiate that returns of Sensex index does not lead to increase in gold price and rise in gold price does not lead to increase in Sensex.

Maysami Ramin, Cooper and Howe Lee, Chuin and Hamzah Mohamad, Atkin (2004) examined the long-term equilibrium relationships between selected macroeconomic variables and the Singapore stock market index (STI), as well as with various Singapore Exchange Sector indices - the finance index, the property index, and the hotel index and concluded that the Singapore's stock market and the property index form co-integrating relationship with changes in the short and long-term interest rates, industrial production, price levels, exchange rate and money supply. In spite of so many researches on the impact of gold price on the Stock Market indices, few studies have addressed the impact of gold prices on NSE index namely Nifty right from its inception, especially by analyzing the day to day index and gold prices. Hence, the present study probes into the research gap identified and makes an attempt to explore the relationship between Indian National Stock Exchange index namely Nifty 50 and the gold price by analyzing a long term period of 24 years spanning over 1992, the inception year of NSE to 2016, that too based on daily price observations.

\section{Objectives:-}

Though studies from different perspectives examine the relationship, empirical analysis of relationship between capital market and preferred alternative investment in gold still needs verification. The extent of cause effect relationship of gold prices on National Stock Exchange Index, Nifty using sophisticated econometric techniques become imperative in the context of aftermath recovery of a global recession. The following specific objectives were identified

1. To explore the extent of linkages between gold prices and Nifty

2. To validate the relationship between the independent variable daily gold price and dependent variable daily close price of Nifty

3. To explain the causal relationship between the identified variables in long-run and short-run as well. 


\section{Methodology:-}

\section{Data source:-}

The study is entirely based on secondary data collected from official data sources. With a view to analyse the causal relationship between the variables, the study takes into account the daily closing price of $\boldsymbol{N S E}$ index i.e. Nifty 50 and the daily gold price per gram in Indian Rupees for a period of 24 years from $2^{\text {nd }}$ April 1992 to $8^{\text {th }}$ July 2016 , which were collected from the official websites i.e. historical index data from /https://www.nseindia.com/products/content/equities/indices/historical_index_data.htm and daily gold prices from http://www.gold.org/research/download-the-gold-price-since-1978. The analysis has been done using econometric software called Eviews 9.

\section{Data Cleaning and Manipulation:-}

The data obtained regarding daily prices of gold and that of Nifty had shown a number of mismatches that necessitated data cleaning extensively. Since the stock exchanges in India are closed on special Indian holidays such as Republic day, Independence day, Gandhi Jayanti etc. the gold prices of such dates were first removed for all the years. Similarly gold market rates were not available for certain dates on which the National Stock Exchange was functioning and the close prices of Nifty on that dates needed to be removed by manual inspection of observations compiled. After such cleaning process data had to be manipulated in terms of conversion of gold price per ounce to gold price per gram. For this purpose, the gold price in Indian Rupee per ounce was divided by 31.1034768 in the excel sheet before importing such data into Eviews. Altogether 5895 observations of both the independent variable gold price in Indian Rupee per gram and dependent variable close price of Nifty pertaining to a 24 year period from $2^{\text {nd }}$ April 1992 to $8^{\text {th }}$ July 2016 were made available.

\section{Research Methods:-}

The research methods used for the study conform to standard econometric models and the observation data relating to both the variables were transformed to their logarithm values. The descriptive statistics of both the variables were identified and the empirical distribution test was conducted on both the logged variables to decide on their normal distribution status. Further the Unit roost (augmented Dickey Fuller) tests were conducted on both the variables to test the null hypotheses that the series has a unit root. After confirming the stationary nature of both the time series, the coefficient correlation between them and original least square regression were estimated. In addition Granger causality analysis (GCA) of each variable does not or does granger cause is tested. In order to avoid co-integration between the variable to influence the finding Johansen's Co-integration test was conducted and based on the findings the VECM was analysed. The new regression equations with correction factors and coefficients necessary were obtained before running their Least Squares (Gauss-Newton / Marquardt steps). Wald test and Variance Inflation Factors (VIF) were analysed before ensuring validity of the model and concluding the findings.

\section{Experimental Results:-}

The 5895 observations each of both data sets namely daily close prices of nifty and daily prices of gold per gram in Indian Rupees were first transformed into their logarithm values before applying differencing of the first order wherever necessary, so that the stationary nature of the data series could be ensured after appropriate tests.

\section{Descriptive Statistics :-}

The descriptive statistics of variables under study namely log Nifty 50 (dependent) and log Gold price/gm in Indian Rupees (Independent), both on a daily basis, is subjected to analysis before proceeding with the check for its stationary nature. The descriptive statistics of the variables mentioned comprising of 5895 observations each, relating to a period of 24 years, spanning over $1^{\text {st }}$ April 1992 to $8^{\text {th }}$ July 2016 are presented in Table 1. 
Table 1:- Descriptive Statistics for dependent Variable Nifty 50 and Independent variable.

\begin{tabular}{|l|l|l|}
\hline & LGOLD & LNIFTY \\
\hline Mean & 6.697737 & 7.730084 \\
\hline Median & 6.385835 & 7.501027 \\
\hline Maximum & 8.051125 & 9.104563 \\
\hline Minimum & 5.697919 & 6.396113 \\
\hline Std. Dev. & 0.769411 & 0.803066 \\
\hline Skewness & 0.477666 & 0.212231 \\
\hline Kurtosis & 1.610346 & 1.455901 \\
\hline Jarque-Bera & 698.5083 & 629.8833 \\
\hline Probability & 0.000000 & 0.000000 \\
\hline Sum & 39483.16 & 45568.84 \\
\hline Sum Sq. Dev. & 3489.210 & 3801.128 \\
\hline Observations & 5895 & 5895 \\
\hline
\end{tabular}

Among the two series, Nifty appears to have a wider spread as is obvious from its higher standard deviation. Skewness being positive for both the variables indicates flat tails on the right hand side of the distribution which hints the fact that the distribution is not normally distributed. As is known data that follow a normal distribution perfectly have a kurtosis value of 3 and distribution with a positive kurtosis value indicates that the distribution has heavier tails and a sharper peak than the normal distribution. However in this case both the variables are deviated since kurtosis is both the cases are not near 3 values.

The Jarque Bera Test:-

The Jarque Bera test is based on the sample skewness and sample kurtosis. The Jarque-Bera test statistic is defined as

$$
\frac{N}{6}\left(S^{2}+\frac{(k-3)}{4}\right)
$$

where $S, K$, and $N$ denote the sample skewness, the sample kurtosis, and the sample size, respectively.

The following hypotheses were tested using the Jarque Bera test of normality.

- $\quad$ Null $\mathrm{H}_{0}=$ the population is normally distributed

- Alternative $\mathrm{H}_{1}=$ the population is not normally distributed

As is evident from Table 1, the Jarque Bera statistic of gold price and nifty were 698.5083 and 629.8833 respectively both with a probability of 0.0000 each. Thus the Jarque-Bera test of normality applied on the frequency distribution confirms the fact that the distribution does not follow normal distribution as the p-values of the variables are less than 0.05 . Hence the null hypothesis of the presence of normality in the frequency distribution can be rejected.

\section{Empirical Distribution Tests:-}

The empirical distribution tests are based on the comparison between the empirical distribution and the specified theoretical distribution function. The empirical distribution test on logged values of Nifty as well as Gold also rejects the hypothesis that the distribution is normal as is clear from the results shown in Table 2 
Table 2:- Empirical Distribution Test for LOG NIFTY and LGOLD.

\begin{tabular}{|c|c|c|c|c|c|c|c|c|}
\hline \multicolumn{9}{|c|}{ Hypothesis: Normal } \\
\hline \multicolumn{9}{|c|}{ Sample: 4/02/1992 7/08/2016 } \\
\hline \multicolumn{9}{|c|}{ Included observations: 5895} \\
\hline & \multicolumn{3}{|l|}{ LNIFTY } & \multicolumn{3}{|l|}{ LGOLD } & & \\
\hline Method & Value & $\begin{array}{l}\text { Adj. } \\
\text { Value }\end{array}$ & Probability & Value & $\begin{array}{l}\text { Adj. } \\
\text { Value }\end{array}$ & Probability & & \\
\hline Lilliefors (D) & 0.16292 & NA & 0 & 0.17677 & NA & 0 & & \\
\hline $\begin{array}{l}\text { Cramer-von Mises } \\
\text { (W2) }\end{array}$ & 47.4368 & 47.4408 & 0 & 56.0234 & 56.0281 & 0 & & \\
\hline Watson (U2) & 46.9443 & 46.9483 & 0 & 53.5568 & 53.5614 & 0 & & \\
\hline $\begin{array}{l}\text { Anderson-Darling } \\
\text { (A2) }\end{array}$ & 274.477 & 274.512 & 0 & 346.5 & 346.544 & 0 & & \\
\hline \multicolumn{9}{|c|}{ Method: Maximum Likelihood - d.f. corrected (Exact Solution) } \\
\hline & \multicolumn{4}{|c|}{ LNIFTY } & \multicolumn{4}{|l|}{ LGOLD } \\
\hline Parameter & Value & $\begin{array}{l}\text { Std. } \\
\text { Error }\end{array}$ & z-Statistic & Prob. & Value & Std. Error & $\begin{array}{l}\text { Z- } \\
\text { Statistic }\end{array}$ & Prob. \\
\hline MU & 7.73008 & 0.01046 & 739.052 & 0 & 6.69774 & 0.01002 & 668.362 & 0 \\
\hline SIGMA & 0.80307 & 0.0074 & 108.573 & 0 & 0.76941 & 0.00709 & 108.573 & 0 \\
\hline Log likelihood & -7071.3 & \multicolumn{2}{|c|}{ Mean dependent var. } & 7.73008 & -6818.9 & \multicolumn{2}{|c|}{ Mean dependent var. } & 6.69774 \\
\hline No. of Coefficients & 2 & S.D. dep & ndent var. & 0.80307 & 2 & S.D. depen & ent var. & 0.76941 \\
\hline
\end{tabular}

All the tests for empirical distribution revealed a $\mathrm{p}$ value of $<0.05$ leading to rejection of null hypothesis that the distributions of $\log$ nifty as well as $\log$ gold prices per gram are normally distributed.

\section{Unit Root Tests:-}

A series is said to be (weakly or covariance) stationary if the mean and auto co variances of the series do not depend on time. Any series that is not stationary is said to be non stationary. A common example of a non stationary series is the random walk:

$\mathrm{y}_{\mathrm{t}}=\mathrm{y}_{\mathrm{t}-1}+\varepsilon_{\mathrm{t}}$

where $\varepsilon$ is a stationary random disturbance term. The series y has a constant forecast value, conditional on $t$, and the variance is increasing over time. The random walk is a difference stationary series since the first difference of y is stationary:

$\mathrm{y}_{\mathrm{t}}-\mathrm{y}_{\mathrm{t}-1}=\varepsilon_{\mathrm{t}}$

A difference stationary series is said to be integrated and is denoted as $\mathrm{I}(\mathrm{d})$ where $\mathrm{d}$ is the order of integration. The order of integration is the number of unit roots contained in the series, or the number of differencing operations it takes to make the series stationary.

The unit root tests (see table 3) applied on both the level and first difference values of both dependent and independent variables, to check the stationary aspects, reveals that after first differencing both the variables become stationary and the random walk gets eliminated as is observed from figures 1 and 2. In both the cases, the hypothesis that the differenced variable has a unit root is rejected at $1 \%$ level, absolute $\mathrm{t}$ value being higher than absolute critical values at $5 \%$ and even $1 \%$ with $\mathrm{p}$ value less than 0.05 . 
Table 3:- Unit Root Tests.

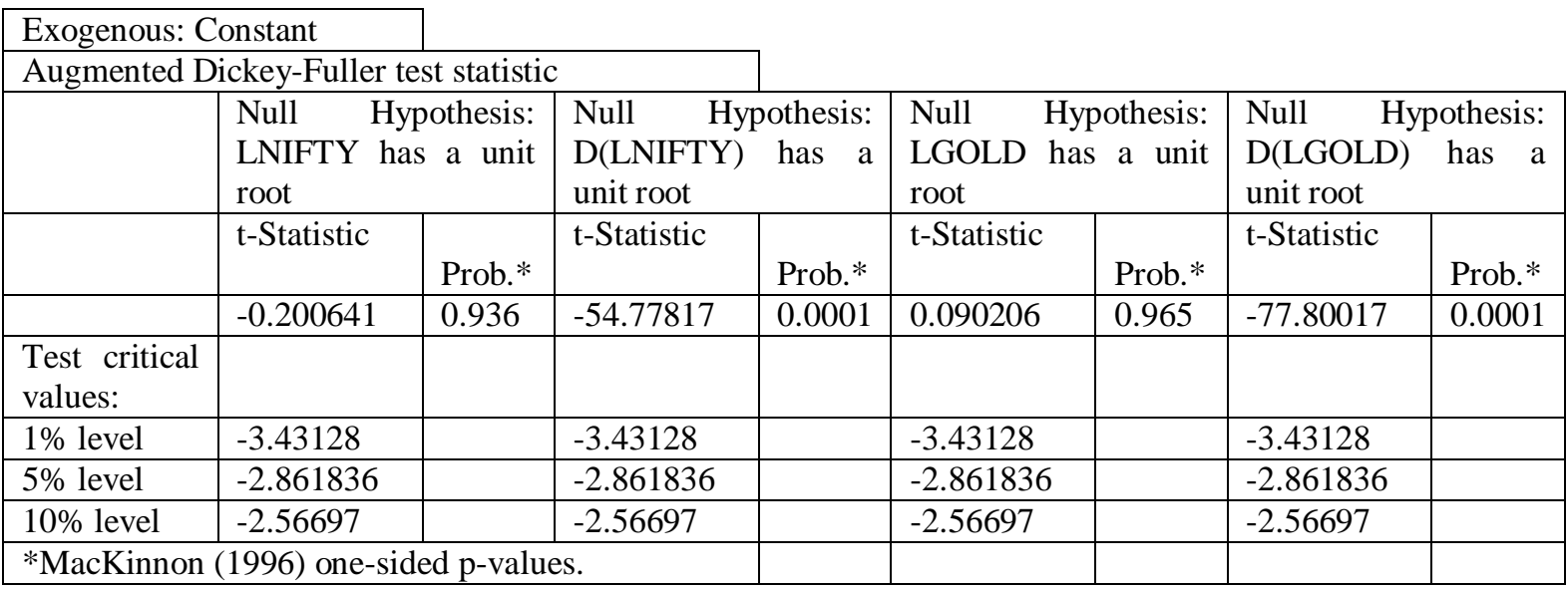

Figure 1 and figure 2 illustrates the graphical representation of differenced log nifty and difference log gold prices which substantiates the stationary nature of the series of observations.

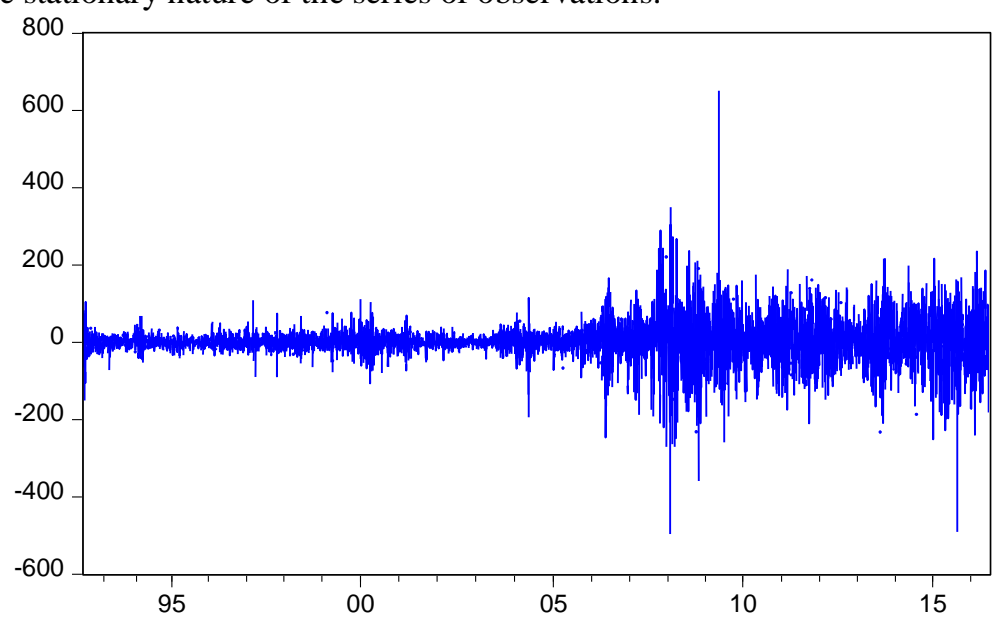

Fig 1 Differenced Log Nifty

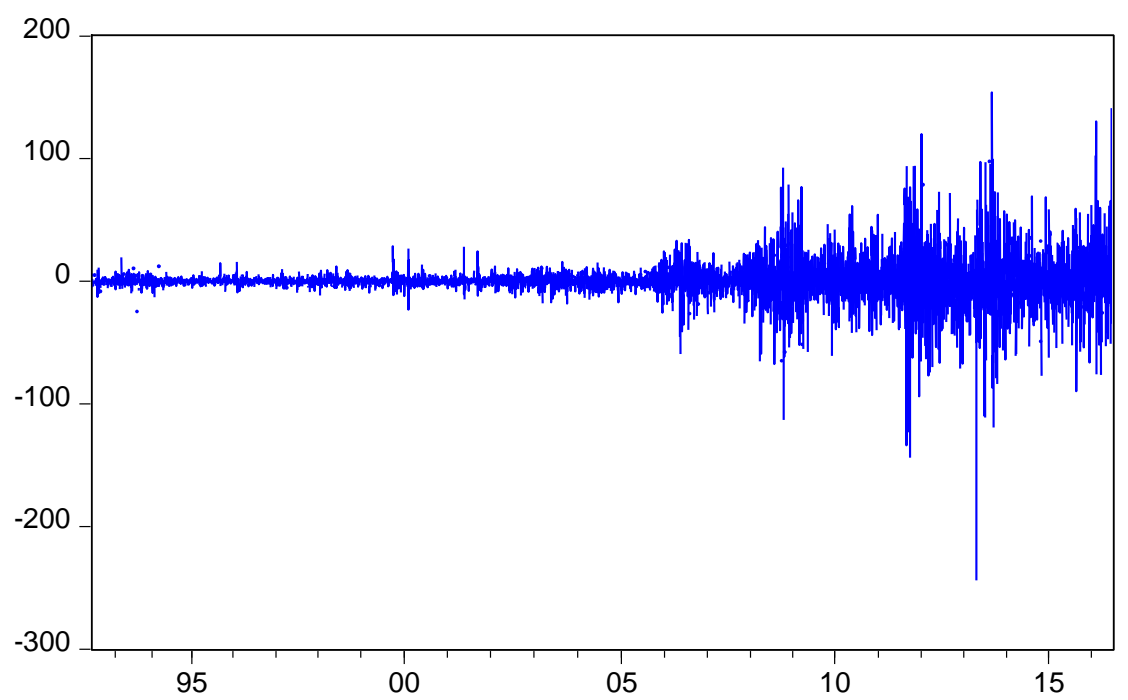

Fig 2 Differenced Log Goldprice 


\section{Correlation between Nifty and Gold Prices:-}

Correlation analysis is normally used to depict the linear association between the variables. With a view to identify the linear association that is expected to exist between capital markets and investment in gold, the correlation coefficient between gold prices and nifty index is subjected to analysis. From the correlation matrix as is tabulated in table 4, it may be observed that there is significant negative correlation between nifty and gold prices, indicating that a decrease in nifty causes further investment in a safe investment avenue namely, gold.

Table 4:- Correlation between first differenced logged variables Gold Price and Nifty

\begin{tabular}{|l|l|l|}
\hline & DLGOLD & DLNIFTY \\
\hline DLGOLD & 1 & -0.05223556222197056 \\
\hline DLNIFTY & -0.05223556222197056 & 1 \\
\hline
\end{tabular}

\section{Regression analysis:-}

The aim of regression analysis is to take a purely theoretical equation

$Y_{t}=\beta_{0}+\beta_{1} X_{1}+\varepsilon_{1}$

and use a set of data to create an estimated equation like

$\hat{Y}=\widehat{\beta}_{0}+\widehat{\beta}_{1} X_{1}$

Where each hat $(\wedge)$ indicates a sample estimate of the true population value.

Ordinary least squares, referred to as OLS, is one of the most common techniques used in multivariate analysis. OLS is a regression estimation technique that calculates the $\widehat{\beta}$ s so as to minimize the sum of squared residuals.

A least square estimation using ordinary least squares method with the following hypotheses was made to verify the influence of differenced log values of independent variable gold price on dependent variable nifty index. The results are tabulated as table 5 below.

Hypothesis:-

H0: Independent variable cannot influence dependent variable.

H1: Independent variable influences the dependent variable.

Table 5:- Original Least Square Regression Output.

\begin{tabular}{|c|c|c|c|c|}
\hline \multicolumn{5}{|c|}{ Dependent Variable: DLNIFTY } \\
\hline \multicolumn{5}{|c|}{ Method: Least Squares } \\
\hline \multicolumn{5}{|c|}{ Sample (adjusted): 4/03/1992 7/08/2016 } \\
\hline \multicolumn{5}{|c|}{ Included observations: 5894 after adjustments } \\
\hline Variable & Coefficient & Std. Error & t-Statistic & Prob. \\
\hline $\mathrm{C}$ & 0.000349 & 0.000211 & 1.649427 & 0.0991 \\
\hline DLGOLD & -0.080497 & 0.020049 & -4.015050 & 0.0001 \\
\hline R-squared & 0.002729 & \multicolumn{2}{|c|}{ Mean dependent var } & 0.000318 \\
\hline Adjusted R-squared & 0.002559 & \multicolumn{2}{|c|}{ S.D. dependent var } & 0.016239 \\
\hline S.E. of regression & 0.016218 & \multicolumn{2}{|c|}{ Akaike info criterion } & -5.405023 \\
\hline Sum squared resid & 1.549777 & \multicolumn{2}{|c|}{ Schwarz criterion } & -5.402756 \\
\hline Log likelihood & 15930.60 & \multicolumn{2}{|c|}{ Hannan-Quinn criter. } & -5.404235 \\
\hline F-statistic & 16.12063 & \multirow{2}{*}{\multicolumn{2}{|c|}{ Durbin-Watson stat }} & 1.829469 \\
\hline Prob(F-statistic) & 0.000060 & & & \\
\hline
\end{tabular}

The rules of statistical tests favour rejecting null hypothesis and accepting alternative, whenever the p-value is less than $5 \%(0.05)$, The model explains only $2.72 \%$ of the variation in the dependent variable, as is obvious from the Rsquared. The adjusted R-squared indicates the explanatory power of the model. A very low R squared and adjusted $\mathrm{R}$ squared in this case may point out weakness in the model that can be interpreted as explanatory variable i.e. gold price by itself is statistically insignificant to explain the variation in the dependent variable Nifty. Further the estimated t-statistic may be considered and if the absolute value of the explanatory variables is less than 1.96, the 
statement that the explanatory variable gold price is insignificant. However in our case, the absolute value of the tstatistic of the explanatory variable is greater than 2 and with the corresponding p-value being less than 0.05 , rejecting the null hypothesis, that the independent variable cannot influence the dependent variable, becomes inevitable. The alternate hypothesis that independent variable influences the dependent variable is thus accepted, underlining the influence of gold prices on stock market investments and subsequently the Nifty.

\section{Durbin Watson Statistic:-}

The presence of autocorrelation between the individual observations in the differenced data can jeopardize the above finding that independent variable namely gold prices influence the stock market index. To substantiate the influence of gold prices on nifty, the Durbin Watson statistic may be made use of. A Durbin Watson statistic approaching zero is normally considered as indication of positive autocorrelation while one approaching 4 is considered as an indication of negative correlation between differenced observations in the time series under review here. The generally accepted Durbin Watson Statistic of near 2 rules out the possibility of auto correlation among differenced observations which is true in our case as is evident from a Durbin Watson statistic of 1.83 (see table 5), much closer to the desired value of 2 . Hence the relation of influence established between gold prices and nifty cannot be overruled on account of existence of auto correlation between observations in the time series data even after their first differencing.

\section{Granger Causality Test:-}

Correlation does not necessarily imply causation in any meaningful sense of that word. The econometric graveyard is full of magnificent correlations, which are simply spurious or meaningless. The Granger (1969) approach to the question of whether $\mathrm{x}$ causes $\mathrm{y}$ is to see how much of the current $\mathrm{y}$ can be explained by past values of $\mathrm{y}$ and then to see whether adding lagged values of $\mathrm{x}$ can improve the explanation. $\mathrm{Y}$ is said to be Granger-caused by $\mathrm{x}$ if $\mathrm{x}$ helps in the prediction of $y$, or equivalently if the coefficients on the lagged x's are statistically significant.

Granger causality analysis (GCA) is a method for investigating whether one time series can correctly forecast another (Granger, 1969). Table 6 depicts the Granger causality test results, a method based on multiple regression analysis to check the short-run causal relation among the variables.

Table 6:- Pair wise Granger Causality Tests.

\begin{tabular}{|l|c|c|c|}
\hline Lags: 2 & Obs & F-Statistic & Prob. \\
\hline Null Hypothesis: & 5892 & 0.33739 & 0.7136 \\
\hline DLNIFTY does not Granger Cause DLGOLD & & 3.11283 & 0.0445 \\
\hline DLGOLD does not Granger Cause DLNIFTY & & & 0 \\
\hline
\end{tabular}

A p-value of 0.7136 ( $p>0.05)$ accepts the null hypothesis and points out the fact that Nifty does not granger cause gold price, when a lag of 2 is considered, notwithstanding the fact that an increased lag of 52 covering a 52 week period can cause Nifty to granger cause gold price. On the other hand, null hypothesis is rejected even at lag 2 with $\mathrm{p}$ value of 0.0445 ( $\mathrm{p}<0.05)$, accepting the alternate hypothesis that gold price granger causes the Nifty. This throws light on the fact that there prevails unidirectional relationship between the variables in short run which runs from gold price to nifty and not vice versa. In order to check their long-run relationship we will go for co integration test and error correction model further.

\section{Johansen Co integration test:-}

The finding that many macro time series may contain a unit root has spurred the development of the theory of nonstationary time series analysis. Engle and Granger (1987) pointed out that a linear combination of two or more nonstationary series may be stationary. If such a stationary linear combination exists, the non-stationary time series are said to be co-integrated. The stationary linear combination is called the co-integrating equation and may be interpreted as a long-run equilibrium relationship among the variables. The Johansen test and estimation strategy maximum likelihood - makes it possible to estimate all co-integrating vectors when there are more than two variables. [Dwyer P Gerald P (2015)]. If there are three variables each with unit roots, there are at most two cointegrating vectors. More generally, if there are $n$ variables which all have unit roots, there are at most $n-1$ cointegrating vectors. The Johansen test provides estimates of all co-integrating vectors. Just as for the Dickey-Fuller test, the existence of unit roots implies that standard asymptotic distributions do not apply. Table 7 depicts the results of Johansen's Co-integration test applied to the variables studied. 
Table 7:- Johansen Co-integration Test.

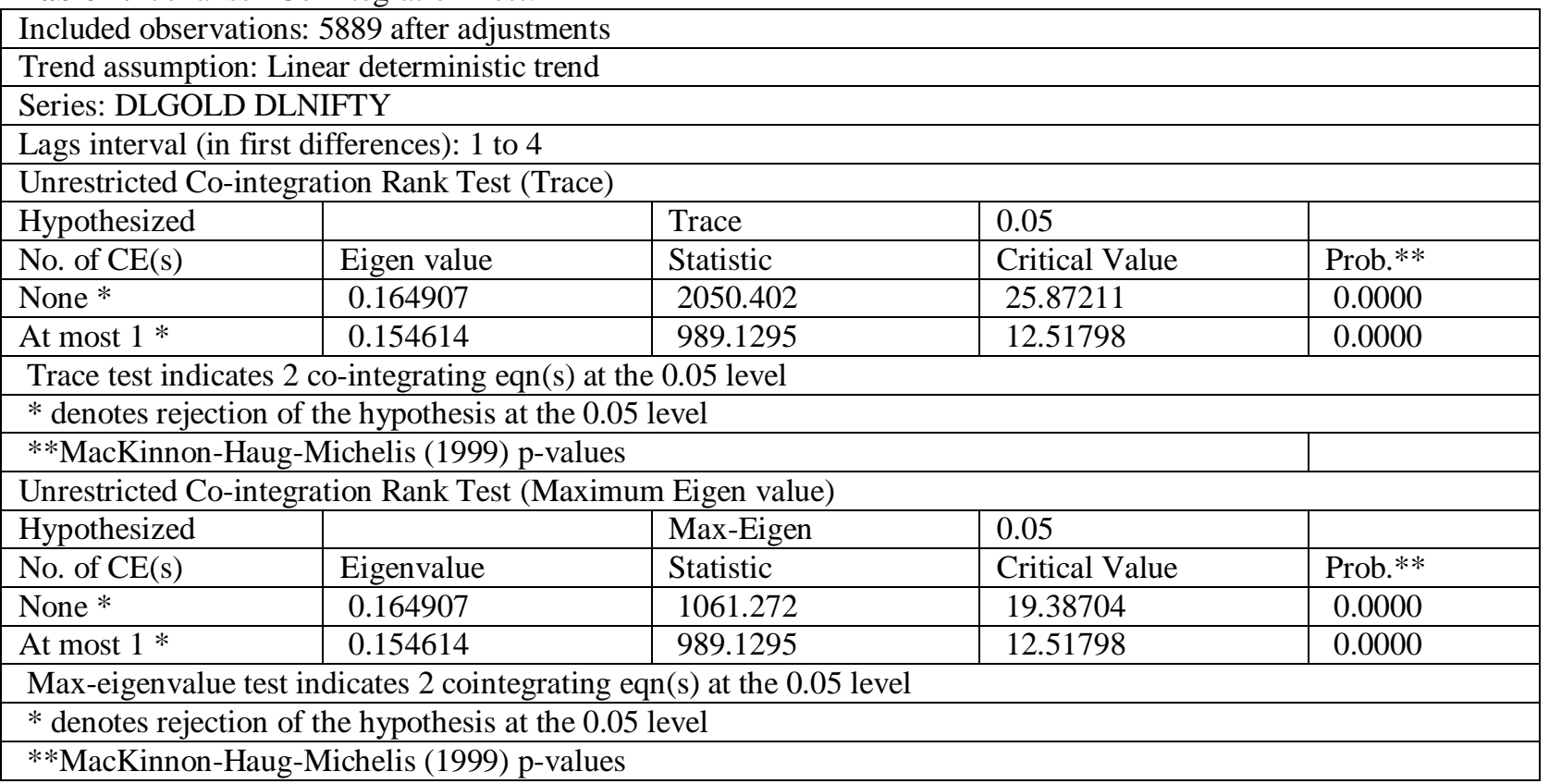

The result of the Johansen co-integration test, which is fairly different from the result of Granger causality test, revealed the existence of stochastic trends in the variables under review. The absolute value of the estimated trace statistic is greater than its tabulated value. Hence, the null hypothesis of no co-integration is rejected at $5 \%$ level of significance. The same holds for the eigen-value as well. Hence, further testing of the null hypothesis of at most one co-integration relation between the variables becomes necessary. Here, also we reject the null hypothesis suggesting that there are two significant co-integrating vectors in the model, which implies that there are two common stochastic trends, indicating a degree of integration between the two markets. Now the use of co-integrating equations can be relied on and hence the Vector Error Correction Model (VECM) is applied.

Vector Error Correction Model (VECM):-

A vector error correction (VEC) model is a restricted VAR designed for use with non-stationary series that are known to be co-integrated. The VEC has co-integration relations built into the specification so that it restricts the long-run behavior of the endogenous variables to converge to their co-integrating relationships while allowing for short-run adjustment dynamics. The co-integration term is known as the error correction term since the deviation from long-run equilibrium is corrected gradually through a series of partial short-run adjustments. The VECM analysis in order to decide whether the error term adjusts itself to move into the long run equilibrium and if so what is the error correction term resulting from partial short run adjustments has been made and results are tabulated in table 8 .

Table 8:- Vector Error Correction Estimates.

\begin{tabular}{|l|l|l|}
\hline Sample (adjusted): 4/08/1992 7/08/2016 \\
\hline Included observations: 5891 after adjustments \\
\hline Standard errors in ( ) \& t-statistics in [ ] & \\
\hline Co-integrating Eq: & CointEq1 & \\
\hline DLNIFTY(-1) & 1.000000 & \\
\hline & & \\
\hline DLGOLD(-1) & -3.289787 & \\
\hline & $(0.08465)$ & D(DLGOLD) \\
\hline C & {$[-38.8639]$} & 0.240987 \\
\hline Error Correction: & 0.000909 & D(DLNIFTY) \\
\hline CointEq1 & -0.209121 & \\
\hline
\end{tabular}




\begin{tabular}{|l|c|c|}
\hline & $(0.01052)$ & $(0.00637)$ \\
\hline & {$[-19.8770]$} & {$[37.8259]$} \\
\hline D(DLNIFTY(-1)) & -0.448689 & -0.149599 \\
\hline & $(0.01361)$ & $(0.00824)$ \\
\hline D(DLNIFTY(-2)) & {$[-32.9605]$} & {$[-18.1477]$} \\
\hline & -0.279754 & -0.068068 \\
\hline D(DLGOLD(-1)) & $(0.01238)$ & $(0.00750)$ \\
\hline & {$[-22.5939]$} & {$[-9.07822]$} \\
\hline & -0.481282 & -0.148088 \\
\hline D(DLGOLD(-2)) & $0.02924)$ & $(0.01771)$ \\
\hline & {$[-16.4610]$} & {$[-8.36409]$} \\
\hline & -0.224362 & -0.100291 \\
\hline C & $(0.02142)$ & $(0.01297)$ \\
\hline & {$[-10.4728]$} & {$[-7.73068]$} \\
\hline & $6.68 \mathrm{E}-06$ & $3.52 \mathrm{E}-06$ \\
\hline R-squared & $(0.00023)$ & $(0.00014)$ \\
\hline Adj. R-squared & {$[0.02855]$} & {$[0.02486]$} \\
\hline Sum sq. resids & 0.332031 & 0.475112 \\
\hline S.E. equation & 0.331464 & 0.474666 \\
\hline F-statistic & 1.898218 & 0.696079 \\
\hline Log likelihood & 0.017960 & 0.010876 \\
\hline Akaike AIC & 585.0580 & 1065.385 \\
\hline Schwarz SC & 15323.64 & 18278.58 \\
\hline Mean dependent & -5.200352 & -6.203559 \\
\hline S.D. dependent & -5.193547 & -6.196754 \\
\hline Determinant resid covariance (dof adj.) & $1.36 \mathrm{E}-06$ & $1.85 \mathrm{E}-06$ \\
\hline Determinant resid covariance & 0.021965 & 0.015005 \\
\hline Log likelihood & & $3.80 \mathrm{E}-08$ \\
\hline Akaike information criterion & & $3.79 \mathrm{E}-08$ \\
\hline Schwarz criterion & & 33614.68 \\
\hline & & -11.40746 \\
\hline & & -11.39158 \\
\hline & & \\
\hline & & \\
\hline
\end{tabular}

The intercept of the co-integrating relation is near zero and is significant with absolute t-value 2 in the case of both differenced log of gold prices and nifty. This can be seen as an implication that that the error term adjusts itself to move into the long run equilibrium. How fast the adjustment takes place can be determined from the estimated coefficient of the error correction term, which in this case is 0.209 i.e. $20.9 \%$. The long run relationship among the variables is thus established. It is worth noting that both the one- period and two period lagged value of Nifty can statistically point out the significance of the variation in the current period gold price which is clear from the estimated t-statistic. Once again, both the one-period and two period lagged values of the gold price can statistically and significantly explain the variation in the current period Nifty. In the second equation of the VECM, the coefficient of the error correction is non-negative though the t-statistic is greater than two, which implies that the error term does not adjust itself to move into the long run equilibrium. Both the models are not statistically that significant as is obvious from the corresponding Adjusted $\mathrm{R}^{2}$ statistics which are 0.33 and 0.47 respectively. This implies that 33 percent of the variation in the explained variable in Model I have been explained by all the explanatory variables taken together and 47 percent of the variation in the explained variable in Model II has been explained by the explanatory variables. The following system is made by order of variable for applying OLS model again.

$\mathrm{D}($ DLNIFTY $)=\mathrm{C}(1) *($ DLNIFTY(-1) $-3.28978653682 * \mathrm{DLGOLD}(-1)+0.000908955484613)+$ $\mathrm{C}(2) * \mathrm{D}(\mathrm{DLNIFTY}(-1))+\mathrm{C}(3) * \mathrm{D}($ DLNIFTY $(-2))+\mathrm{C}(4) * \mathrm{D}(\mathrm{DLGOLD}(-1))+$ $\mathrm{C}(5) * \mathrm{D}(\mathrm{DLGOLD}(-2))+\mathrm{C}(6)$ 
$\mathrm{D}(\mathrm{DLGOLD})=\mathrm{C}(7) *(\operatorname{DLNIFTY}(-1)-3.28978653682 * \mathrm{DLGOLD}(-1)+0.000908955484613)+$ $\mathrm{C}(8) * \mathrm{D}(\mathrm{DLNIFTY}(-1))+\mathrm{C}(9) * \mathrm{D}(\mathrm{DLNIFTY}(-2))+\mathrm{C}(10) * \mathrm{D}(\mathrm{DLGOLD}(-1))+$ $\mathrm{C}(11) * \mathrm{D}(\mathrm{DLGOLD}(-2))+\mathrm{C}(12)$

$\mathrm{C}(1)$ and $\mathrm{C}(7)$ in the above equation, represents the coefficient of the error correction terms in the two models. In order to be statistically significant they have to be negative for long run adjustment of the variables. The short run impact of the explanatory variables on the explained variable in Model I are shown by the coefficients $\mathrm{C}(2)$, $\mathrm{C}(3)$, $\mathrm{C}(4)$ and $\mathrm{C}(5)$ while $\mathrm{C}(6)$ is the intercept term in the first model. Similarly, the short run impact of the explanatory variables on explained variables in model II are shown by coefficients $C(8), C(9), C(10)$ and $C(11)$ while coefficient $\mathrm{C}(12)$ is the intercept term in the second model. At this point of time we can apply Wald Test to find out the joint significance of both the period lagged values of a particular explanatory variable on the explained variable.

\section{OLS Models of Corrected Equations:-}

The above stated equations are run one by one as OLS models and the results are tabulated in table 9 and table 10.

Table 9:- Original Least Square Estimate of Corrected Model I.

\begin{tabular}{|c|c|c|c|c|}
\hline \multicolumn{5}{|c|}{ Dependent Variable: D(DLNIFTY) } \\
\hline \multicolumn{5}{|c|}{ Method: Least Squares (Gauss-Newton / Marquardt steps) } \\
\hline \multicolumn{5}{|c|}{ Sample (adjusted): 4/08/1992 7/08/2016 } \\
\hline \multicolumn{5}{|c|}{ Included observations: 5891 after adjustments } \\
\hline \multicolumn{5}{|c|}{$\begin{aligned} \mathrm{D}(\mathrm{DLNIFTY})= & \mathrm{C}(1) *(\mathrm{DLNIFTY}(-1)-3.28978653682 * \mathrm{DLGOLD}(-1)+.000908955484613)+ \\
& \mathrm{C}(2) * \mathrm{D}(\mathrm{DLNIFTY}(-1))+\mathrm{C}(3) * \mathrm{D}(\mathrm{DLNIFTY}(-2))+\mathrm{C}(4) * \mathrm{D}(\mathrm{DLGOLD}(-1))+ \\
& \mathrm{C}(5) * \mathrm{D}(\mathrm{DLGOLD}(-2))+\mathrm{C}(6)\end{aligned}$} \\
\hline & Coefficient & Std. Error & t-Statistic & Prob. \\
\hline $\mathrm{C}(1)$ & -0.209121 & 0.010521 & -19.87701 & 0.0000 \\
\hline $\mathrm{C}(2)$ & -0.448689 & 0.013613 & -32.96047 & 0.0000 \\
\hline $\mathrm{C}(3)$ & -0.279754 & 0.012382 & -22.59393 & 0.0000 \\
\hline $\mathrm{C}(4)$ & -0.481282 & 0.029238 & -16.46098 & 0.0000 \\
\hline $\mathrm{C}(5)$ & -0.224362 & 0.021423 & -10.47282 & 0.0000 \\
\hline $\mathrm{C}(6)$ & $6.68 \mathrm{E}-06$ & 0.000234 & 0.028555 & 0.9772 \\
\hline R-squared & 0.332031 & \multicolumn{2}{|c|}{ Mean dependent var } & $1.36 \mathrm{E}-06$ \\
\hline Adjusted R-squared & 0.331464 & \multicolumn{2}{|c|}{ S.D. dependent var } & 0.021965 \\
\hline S.E. of regression & 0.017960 & \multicolumn{2}{|c|}{ Akaike info criterion } & -5.200352 \\
\hline Sum squared resid & 1.898218 & \multicolumn{2}{|c|}{ Schwarz criterion } & -5.193547 \\
\hline Log likelihood & 15323.64 & \multicolumn{2}{|c|}{ Hannan-Quinn criter. } & -5.197986 \\
\hline F-statistic & 585.0580 & \multicolumn{2}{|c|}{ Durbin-Watson stat } & 2.136953 \\
\hline Prob(F-statistic) & 0.000000 & & & \\
\hline
\end{tabular}

Table 10:- Original Least Square Estimate of Corrected Model II.

\begin{tabular}{|c|c|c|c|}
\hline \multicolumn{4}{|c|}{ Dependent Variable: D(DLGOLD) } \\
\hline \multicolumn{4}{|c|}{ Method: Least Squares (Gauss-Newton / Marquardt steps) } \\
\hline \multicolumn{4}{|c|}{ Sample (adjusted): 4/08/1992 7/08/2016 } \\
\hline \multicolumn{4}{|c|}{ Included observations: 5891 after adjustments } \\
\hline \multicolumn{4}{|c|}{$\begin{aligned} \mathrm{D}(\mathrm{DLGOLD})= & \mathrm{C}(7) *(\text { DLNIFTY }(-1)-3.28978653682 * \mathrm{DLGOLD}(-1) \\
& +0.000908955484613)+\mathrm{C}(8) * \mathrm{D}(\mathrm{DLNIFTY}(-1))+\mathrm{C}(9) * \mathrm{D}(\mathrm{DLNIFTY}(-2)) \\
& +\mathrm{C}(10) * \mathrm{D}(\mathrm{DLGOLD}(-1))+\mathrm{C}(11) * \mathrm{D}(\mathrm{DLGOLD}(-2))+\mathrm{C}(12)\end{aligned}$} \\
\hline & Std. Error & t-Statistic & Prob. \\
\hline $\mathrm{C}(7)$ & 0.006371 & 37.82588 & 0.0000 \\
\hline $\mathrm{C}(8)$ & 0.008243 & -18.14770 & 0.0000 \\
\hline $\mathrm{C}(9)$ & 0.007498 & -9.078220 & 0.0000 \\
\hline $\mathrm{C}(10)$ & 0.017705 & -8.364091 & 0.0000 \\
\hline $\mathrm{C}(11)$ & 0.012973 & -7.730681 & 0.0000 \\
\hline $\mathrm{C}(12)$ & 0.000142 & 0.024859 & 0.9802 \\
\hline
\end{tabular}




\begin{tabular}{|l|l|l|l|}
\hline R-squared & 0.475112 & Mean dependent var & $1.85 \mathrm{E}-06$ \\
\hline Adjusted R-squared & 0.474666 & S.D. dependent var & 0.015005 \\
\hline S.E. of regression & 0.010876 & Akaike info criterion & -6.203559 \\
\hline Sum squared resid & 0.696079 & Schwarz criterion & -6.196754 \\
\hline Log likelihood & 18278.58 & Hannan-Quinn criter. & -6.201194 \\
\hline F-statistic & 1065.385 & Durbin-Watson stat & 2.043104 \\
\hline Prob(F-statistic) & 0.000000 & & \\
\hline
\end{tabular}

\section{Wald Tests:-}

Wald tests were conducted on pairs of coefficients [C(2), $\mathrm{C}(3)],[\mathrm{C}(4), \mathrm{C}(5)]$ and $[\mathrm{C}(8), \mathrm{C}(9)],[\mathrm{C}(10), \mathrm{C}(11)]$ and results are tabulated in table 11 and 12 respectively.

The results of the Wald Test applied to make short run decision, prove that for all the coefficients, both the period lagged values of a particular explanatory variable explains statistically significant variation in the corresponding explained variables, Nifty and Gold Price. The p-values of F-statistic and Chi-Square Statistic suggest that the null hypothesis is rejected at 5\% level of significance in all cases.

Table 11:- Wald Test on Pairs of Coefficients C(2), C(3) and C(4), C(5).

\begin{tabular}{|c|c|c|c|c|c|c|c|}
\hline \multicolumn{8}{|c|}{ Wald Tests: Nifty Coefficients } \\
\hline \multicolumn{4}{|c|}{ Equation: $\mathrm{C}(2)=\mathrm{C}(3)=0$} & \multicolumn{4}{|c|}{ Equation: $\mathrm{C}(4)=\mathrm{C}(5)=0$} \\
\hline $\begin{array}{l}\text { Test } \\
\text { Statistic }\end{array}$ & Value & df & Probability & $\begin{array}{l}\text { Test } \\
\text { Statistic }\end{array}$ & Value & df & Probability \\
\hline F-statistic & 566.9714 & $(2,5885)$ & 0.0000 & F-statistic & 136.0689 & $(2,5885)$ & 0.0000 \\
\hline $\begin{array}{l}\text { Chi- } \\
\text { square }\end{array}$ & 1133.943 & 2 & 0.0000 & $\begin{array}{l}\text { Chi- } \\
\text { square }\end{array}$ & 272.1379 & 2 & 0.0000 \\
\hline \multicolumn{4}{|c|}{ Null Hypothesis: $C(2)=C(3)=0$} & \multicolumn{4}{|c|}{ Null Hypothesis: $C(4)=C(5)=0$} \\
\hline \multicolumn{4}{|c|}{ Null Hypothesis Summary: } & \multicolumn{4}{|c|}{ Null Hypothesis Summary: } \\
\hline \multicolumn{2}{|c|}{$\begin{array}{l}\text { Normalized Restriction (= } \\
0 \text { ) }\end{array}$} & Value & Std. Err. & \multicolumn{2}{|c|}{$\begin{array}{l}\text { Normalized Restriction (= } \\
0 \text { ) }\end{array}$} & Value & Std. Err. \\
\hline \multicolumn{2}{|c|}{$\mathrm{C}(2)$} & -0.44869 & 0.013613 & \multicolumn{2}{|c|}{$\mathrm{C}(4)$} & -0.48128 & 0.029238 \\
\hline \multicolumn{2}{|l|}{$\mathrm{C}(3)$} & -0.27975 & 0.012382 & \multicolumn{2}{|l|}{$\mathrm{C}(5)$} & -0.22436 & 0.021423 \\
\hline
\end{tabular}

Table 12:- Wald Test on Pairs of Coefficients C(8), C(9) and C(10), C(11).

\begin{tabular}{|c|c|c|c|c|c|c|c|}
\hline \multicolumn{8}{|c|}{ Wald Tests: Gold Price Coefficients } \\
\hline \multicolumn{4}{|c|}{ Equation: $\mathrm{C}(8)=\mathrm{C}(9)=0$} & \multicolumn{4}{|c|}{ Equation: $C(10)=C(11)=0$} \\
\hline Test Statistic & Value & df & Probability & Test Statistic & Value & df & Probability \\
\hline F-statistic & 164.6743 & $(2,5885)$ & 0.0000 & F-statistic & 38.76884 & $(2,5885)$ & 0.0000 \\
\hline Chi-square & 329.3485 & 2 & 0.0000 & Chi-square & 77.53768 & 2 & 0.0000 \\
\hline \multicolumn{3}{|c|}{ Null Hypothesis: $C(8)=C(9)=0$} & & \multicolumn{3}{|c|}{ Null Hypothesis: $\mathrm{C}(10)=\mathrm{C}(11)=0$} & \\
\hline \multicolumn{3}{|c|}{ Null Hypothesis Summary: } & & \multicolumn{3}{|c|}{ Null Hypothesis Summary: } & \\
\hline \multicolumn{2}{|c|}{ Normalized Restriction $(=0)$} & Value & Std. Err. & \multicolumn{2}{|c|}{ Normalized Restriction $(=0)$} & Value & Std. Err. \\
\hline \multicolumn{2}{|c|}{$\mathrm{C}(8)$} & -0.1496 & 0.008243 & \multicolumn{2}{|l|}{$\mathrm{C}(10)$} & -0.14809 & 0.017705 \\
\hline \multicolumn{2}{|l|}{$\mathrm{C}(9)$} & -0.06807 & 0.007498 & $\mathrm{C}(11)$ & & -0.10029 & 0.012973 \\
\hline
\end{tabular}

\section{Impulse Response Function:-}

Impulse response function is a shock to a VAR system.. A shock to the i-th variable not only directly affects the i-th variable but is also transmitted to all of the other endogenous variables through the dynamic (lag) structure of the VAR. An impulse response function traces the effect of a one-time shock to one of the innovations on current and future values of the endogenous variables. 
Impulse response analysis is another way of inspecting and evaluating the impact of shocks cross section. If the innovations $\varepsilon_{\mathrm{t}}$ are contemporaneously uncorrelated, interpretation of the impulse response is straightforward. The $i^{\text {th }}$ innovation $\varepsilon_{\mathrm{i}, \mathrm{t}}$ is simply a shock to the $\mathrm{i}$-th endogenous variable $\mathrm{Y}_{\mathrm{i}, \mathrm{t}}$. Innovations, however, are usually correlated, and may be viewed as having a common component which cannot be associated with a specific variable. In order to interpret the impulses, it is common to apply a transformation $\mathrm{P}$ to the innovations so that they become uncorrelated.

$v_{\tau}=\Pi \varepsilon_{\tau} \sim(0, \Delta)$, where $\mathrm{D}$ is a diagonal covariance matrix.

Figure 3 illustrates the impulse responses of Nifty to Nifty, Nifty to gold price, gold price to Nifty and gold price to gold price. In the first diagram, Nifty to Nifty, if we give a shock of one standard deviation to Nifty, then the Nifty is going to react to its own shock. The result show that it is responding in positive but gradually going down, falling below zero and eventually reverting to zero. The next figure, depicting the response of Nifty to gold price which hovers around zero, though they are quite stable. It may be observed that the same result holds good for gold price response to Nifty too, which is clear from the next diagram. The last diagram shows the response of gold prices to its own shock. The result is similar to the first one, where gold price is responding in positive but gradually going down even below before recovering to zero

Response of DLNIFTY to DLNIFTY

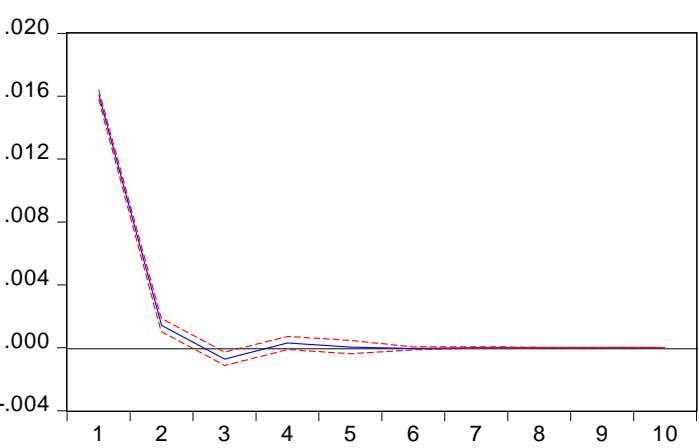

Response of DLGOLD to DLNIFTY

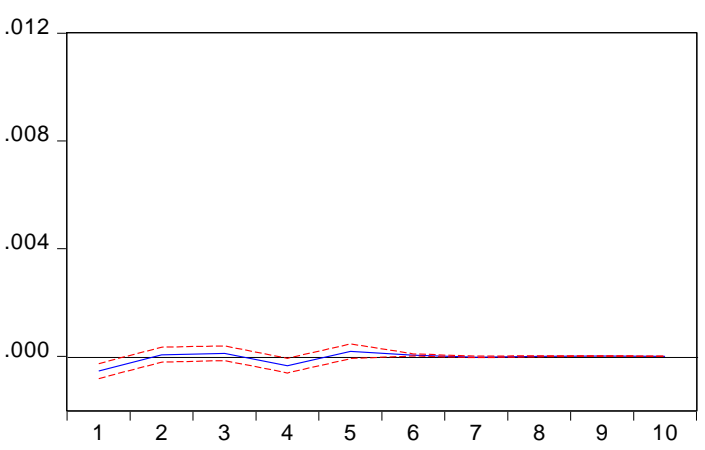

Response of DLNIFTY to DLGOLD

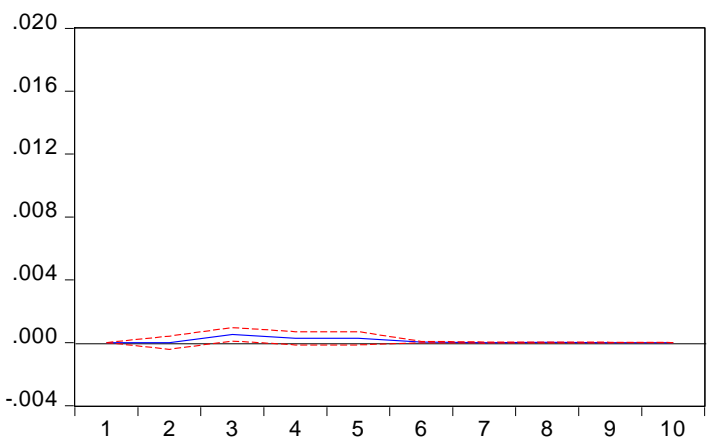

Response of DLGOLD to DLGOLD

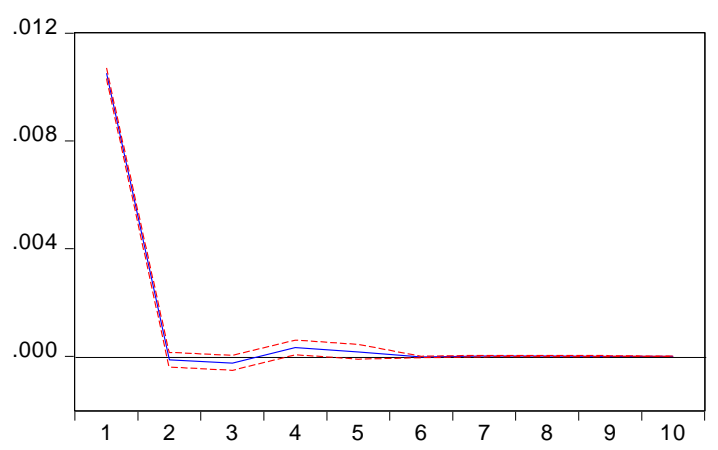

Fig 3 - Period 10 Response to Cholesky One S.D. Innovations \pm 2 S.E.

\section{Variance Decomposition:-}

The Coefficient Variance Decomposition view of an equation provides information on the eigenvector decomposition of the coefficient covariance matrix. This decomposition is a useful tool to help diagnosing potential collinearity problems amongst the regressors.

Yet another method of depicting the system dynamics is the Variance decomposition. While the effects of a shock to an endogenous variable on the variables in the VAR can be traced by Impulse response functions, the variation in an endogenous variable into the component shocks to the endogenous variables in the VAR can be decomposed by Variance decomposition. Hence the variance decomposition can provide valuable information about the relative importance of each random innovation to the variables in the VAR. Table 13 is devoted to summarizing of the 
results on variance decomposition test on dependent variable differenced log nifty and independent variable difference $\log$ gold price.

Table 12:- Variance Decomposition Tests.

\begin{tabular}{|l|l|l|l|}
\hline Variance Decomposition of DLNIFTY: & & & \\
\hline Period & S.E. & DLNIFTY & DLGOLD \\
\hline 1 & 0.016114 & 100.0000 & 0.000000 \\
\hline 2 & 0.016178 & 99.99999 & $8.93 \mathrm{E}-06$ \\
\hline 3 & 0.016202 & 99.89531 & 0.104694 \\
\hline 4 & 0.016207 & 99.86666 & 0.133336 \\
\hline 5 & 0.016209 & 99.83697 & 0.163031 \\
\hline 6 & 0.016209 & 99.83658 & 0.163423 \\
\hline 7 & 0.016209 & 99.83657 & 0.163426 \\
\hline 8 & 0.016210 & 99.83647 & 0.163531 \\
\hline 9 & 0.016210 & 99.83646 & 0.163543 \\
\hline 10 & 0.016210 & 99.83646 & 0.163543 \\
\hline Variance Decomposition of DLGOLD: & & & \\
\hline Period & S.E. & DLNIFTY & DLGOLD \\
\hline 1 & 0.010528 & 0.272077 & 99.72792 \\
\hline 2 & 0.010529 & 0.275099 & 99.72490 \\
\hline 3 & 0.010533 & 0.285096 & 99.71490 \\
\hline 4 & 0.010544 & 0.395433 & 99.60457 \\
\hline 5 & 0.010547 & 0.426563 & 99.57344 \\
\hline 6 & 0.010547 & 0.428513 & 99.57149 \\
\hline 7 & 0.010547 & 0.429325 & 99.57067 \\
\hline 8 & 0.010547 & 0.429332 & 99.57067 \\
\hline 9 & 0.010547 & 0.429370 & 99.57063 \\
\hline 10 & 0.010547 & 0.429371 & 99.57063 \\
\hline Cholesky Ordering: DLNIFTY DLGOLD & & & \\
\hline
\end{tabular}

It may be observed that while variance in Nifty is mostly explained by its own shocks rather than variations in gold prices, a significant variation in gold prices is explained by variation in nifty, when a short period of 10 days is considered.

\section{Conclusion:-}

The switching of from high risk investment avenues to low risk ones even at the cost of sacrificing high, but not so sure, returns is quite common among investors. The extent of information available and low costs associated with such flow of information tends investors to be varied regarding the investment vehicles they choose to invest or continue investing in. The volatility of stock market and its related uncertainty normally tempts investors to divert funds to other investment vehicles, the most popular among such alternatives being gold. The precious metal gold has been an attractive investment traditionally among investors in India, either in the form of jewellery or gold coins. The introduction of derivates and exchange traded funds has further accelerated the move towards gold as an investment. To add fuel to the fire, the global recession and allied stock market crashes across the globe during the latter part of the past decade, witnessed a wild move towards safe investments in gold among panic investors. It is in this context that we examined the relation between gold prices and the emerging stock price index of National Stock Exchange (NSE), India namely Nifty50. An effort was made in this paper to identify the dynamics and intricacies of nexus between the capital market in India represented by NSE and commodity markets represented by gold and thereby establish the impact of gold price on stock market index Nifty vis-à-vis their short-run and long-run causal relationship. In India, investments in stock markets are usually short term and most of investors tend to liquidate their stocks and turn to gold when they fear a fall in stock markets. The analysis conducted by checking the stationary nature of the data and its normality, followed by several relevant tests revealed that there exist a correlation between gold prices and Nifty. It was fascinating to note that the independent variable gold prices influence the dependent variable nifty. Though Nifty does not ganger cause gold prices while the opposite i.e. gold prices do ganger cause Nifty is found to be true which underlines the unidirectional relationship between the two variables. The speed with which the short run disequilibrium adjusts in nifty index was computed and the estimated coefficient of correction term was $20.9 \%$. It was also observed that both the one period and two period lagged values 
statistically explain the variation of gold prices in variations in nifty significantly and vice versa. The favourable property of gold as a safe investment was underlined by the variations in Nifty. The variance decomposition of both the variables revealed that variance in Nifty is mostly explained by its own shocks rather than variations in gold prices but a significant variation in gold prices is explained by variation in nifty, when a short run period is considered.

\section{References:-}

1. Aamir, W., Sohail, N., Sajid, M., \& Kibria, U. (2014). How prices of gold harmonize to stock index: Analysis of South Asian Stock Exchanges.International Journal of Research in Social Sciences, 4(1), 416.

2. Banumathy, K., \& Azhagaiah, R. Causal Relationship between Stock Price and Gold Price in India: A Granger Causality Test Approach. International Journal of Research in Management, Science \& Technology (E-ISSN: 2321-3264) Vol. 2, No. 2, August 2014, 22-27 http://ijrmst.org/download/vol2no2/banumathy.pdf.

3. Banumathy, K., \& Azhagaiah, R. Long-Run and Short-Run Causality between Stock Price and Gold Price: Evidence of VECM Analysis from India, Management Studies and Economic Systems (MSES), 1 (4), 247-256, Spring 2015,247-56, http://msaes.org/article_8804_be2dbc5d257437dd65ba4706ac71e9ca.pdf

4. Dismuke, C., \& Lindrooth, R. (2006). Ordinary least squares. Methods and Designs for Outcomes Research, 93, 93-104.

5. Gayathri, V., \& Dhanabhakyam, M. COINTEGRATION AND CAUSAL RELATIONSHIP BETWEEN GOLD PRICE AND NIFTY-AN EMPIRICAL STUDY.

6. Gupta, S. T. D. B. (2015). Granger Causality of Sensex with Gold Price: Evidence from India. Global Journal of Multidisciplinary Studies, 4(5).[GLOBAL JOURNAL OF MULTIDISCIPLINARY STUDIES ISSN: - 23480459 www.gjms.co.in Volume-4, issue-5 April 2015, 50-54]

7. Johansen, S. (1991). Estimation and Hypothesis Testing of Cointegration Vectors in Gaussian Vector Autoregressive Models. Econometrica, 59(6), 1551-1580. doi:1. Retrieved from http://www.jstor.org/stable/2938278 doi:1

8. Khan, G. S., \& Sarker, S. M. A. E. Dynamic Interactions between Commodity Market and Capital MarketEvidence from India., ASA University Review, Vol. 8 No. 1, January-June, 2014 Dynamic Interactions between Commodity Market and Capital Market - Evidence from India Gholam Syedain Khan* Shah Md. AlEmran Sarker**, 29-45

9. Lawson, C. L., \& Hanson, R. J. (1995). Solving least squares problems (Vol. 15). Philadelphia: Siam.

10. Ramalingam K, How to Invest in Gold in India? Available at at: http://www.moneycontrol.com/news/gold/howto-investgoldindia_983090.html?utm_source=ref_article

11. Ramanathan, K. V., \& Meenakshisundaram, K. S. A Comparative Study Between Various Investment Avenues. IJRAR- International Journal of Research and Analytical Reviews , 74-86 http://ijrar.com/upload_issue/ijrar_issue_260.pdf accessed on 11 July 2016

12. Rubio-Ramirez, J. F., Waggoner, D. F., \& Zha, T. (2010). Structural vector autoregressions: Theory of identification and algorithms for inference. The Review of Economic Studies, 77(2), 665-696.

13. S. P. Narang and R. P. Singh, "Causal relationship between gold price and Sensex: A study in Indian context", Vivekananda Journal of Research, Vol. 1, No. 1, pp. 33-7, 2012.

14. Saluja, Dr. Manminder Singh and Bhatia, Navneet Kaur and Patel, Nishant, A Cointegration and VECM Approach in Explaining Relationship of FDI with Current and Capital Account of India (November 1, 2013). International Journal of Advance Research in Computer Science and Management Studies, Volume 1, Issue 6, November 2013. ISSN: 2321-7782 (Online). Available at SSRN: http://ssrn.com/abstract=2384409

15. Samontaray, D. P., \& Alanuzi, A. A. (2015). The Impact of Gold Price Changes on Saudi Stock Market. In Managing in Recovering Markets (pp. 461-471). Springer India.

16. Shahbaz, M., Tahir, M. I., Ali, I., \& Rehman, I. U. (2014). Is gold investment a hedge against inflation in Pakistan? A co-integration and causality analysis in the presence of structural breaks. The North American Journal of Economics and Finance, 28, 190-205.

17. Shiva, A., \& Sethi, M. (2015). Understanding Dynamic Relationship among Gold Price, Exchange Rate and Stock Markets: Evidence in Indian Context.Global Business Review, $16(5$ suppl), 93S-111S.

18. Srinivasan, P., \& Prakasam, K. (2015). Gold price, stock price and exchange rate nexus: The case of India. Srinivasan P. and Karthigai, P.(2014), Gold Price, Stock Price and Exchange Rate Nexus: The Case of India, The IUP Journal of Financial Risk Management, 11(3), 1-12.

19. Studenmund A H., Using Econometrics, Pearson India Education Services Pvt Ltd, Noida, India 2015

20. The Johansen Tests for Cointegration Gerald P. Dwyer April 2015 available at http://www.jerrydwyer.com/pdf/Clemson/Cointegration.pdf 